\title{
Mini-seedling budding of Hevea brasiliensis: forty years of efforts in China
}

\author{
Xian-hong Chen, Jun Wang, Wei-fu Lin*
}

\author{
Rubber Research Institute, Chinese Academy of Tropical Agricultural Sciences, Danzhou, Hainan 571737, China \\ * Corresponding author Email: rubberl@163.com
}

\begin{abstract}
Good varieties are the basis for long-term high, stable and efficient production of rubber trees. Mini-seedling buddings have the characteristics of short nursery period, low labor intensity, large number of seedlings per unit area, easy transportation and planting, well-developed taproot and intact root system, high survival rate after planting, fast growth, strong tolerance to drought, wind and cold, and early tapping. The application of rubber mini-seedling buddings and its related research were summarized. Finally, the outlook for ongoing research on mini-seedling buddings was prospected.
\end{abstract}

Keywords-Hevea brasiliensis, mini-seedling budding, propagation, application.

\section{INTRODUCTION}

Mini-seedling budding of Hevea brasiliensis is a new propagation technique of elite clone on the basis of traditional budding method, which was developed by Rubber Research Institute, Chinese Academy of Tropical Agricultural Sciences [1-3], and was listed by the Agriculture Ministry of China as the first batch of main push varieties and technology of south subtropical crops during the 11th Five Year Plan period. Mini-seedling budding technique use 2-week-old seedlings, which are pulled out of the germination bed with seeds (nutrient provider for budding and further growing), with about $20 \mathrm{~cm}$ plant height and leaf phenology between elongating stage to leaf-unfolding stage[4-5], as rootstock and green bud- patches as scion[6-14]. The budding operation process is done at indoor, which reduce labor intensity comparison with traditional budding in the field. After budding the budded seedlings are directly transferred into nursery bags or pre-planted on sand bed or nursery trays with some shade. After budding successfully, two compound leaflets are kept on the seedling stocks when topping to avoid dieback [15-16], rootstock bud are picked[17-18], scion bud sprouting [19-23], and the buddings are raised up to 2-3 leaf whorls during 5-8 months with above $0.4 \mathrm{~cm}$ shoot diameter[24-27]. Raising polybag-budding by mini-seedling budding technique are 3-12 months less than those by traditional propagation, which reduce propagation costs and labor intensity and increase nursery productivity per unit area (Table 1). Miniseedling budding shorten rootstock growth time by using small rootstocks for budding. The weight of polybag buddings raised by mini-seedling budding is twice lighter than those raised by compared with the traditional method for raising budded stumps, resulting in lower cost and less labor intensity as well as higher productivity of the nursery per unit area. Mini-seedling buddings with good taproot and intact roots is easy to transport and transplant. In addition, mini-seedling buddings are characterized by high survival rate of field transplanting, fast growth after transplanting, wind tolerance [28], cold resistance [29], and drought resistance [30], early tapping (nearly one year shorter than traditional buddings). Taken together, in contrast to traditional buddings, mini-seedling budding can save cost and increase income by $0.5-1.0$ yuan per plant [ 3 , 31]. The cost of rubber plantation raised by mini-seedling buddings at nursery period and immature period is 6450 yuan per hectare less than that raised by traditional buddings, showing good economic benefits [32].

Table.1:Comparison on nursery time of buddings at 1-3 leaf whorls by different propagation

\begin{tabular}{ccc}
\hline Nursery types & $\begin{array}{c}\text { rootstock } \\
\text { diameter(cm) at } \\
\text { budding }\end{array}$ & $\begin{array}{c}\text { nursery } \\
\text { time(month) }\end{array}$ \\
\hline $\begin{array}{c}\text { polybag budded } \\
\text { stumps }\end{array}$ & $1.50-3.00$ & $\leq 20$ \\
Green budding & $0.60-1.40$ & $\leq 12$ \\
Young budding & $0.40-0.50$ & $\leq 10$ \\
Mini-seedling \\
budding
\end{tabular}

Note: nursery time is from sowing seeds to transfer budded plants out of the nursery. 


\section{RESEARCH AND DEVELOPMENT HISTORY}

Mini-seedling budding of Hevea brasiliensis was begun research in 1980 and begun to take shape in 1983-1984. Reform of scientific research institutions in China was begun in 1986, which meant researchers had to fund their own research. In 1987, Huang Shoufeng group applied for a research loan (3000 yuan) from Rubber Research Institute to multiply mini-seedling buddings, sold them and repaid the loan. Meanwhile, mini-seedling buddings were transplanted in the field. After that, the research of miniseedling budding stagnated without funding. Mini-seedling buddings were raised again in 1996 and prepared for the assessment of scientific and technological achievement in 1998. After appraisal, the research of mini-seedling budding stalled again without funding. Popularization of large-scale trial planting mini-seedling buddings was supported by the earmarked fund for China Agriculture Research System (CARS-34-YZ4) since 2005-2006.

\section{POPULARIZATION OF LARGE-SCALE TRIAL PLANTING}

Mini-seedling budding was introduced and outreached in Hainan Province [33], Yunnan Province [34-36] and Guangdong Province [37-42], respectively. Since its popularization in Yunnan Province in 2003, it has been rapidly recognized by the majority of seedling raising farms and planting farmers. In 2019, the number of rubber mini-seedling buddings promoted by the rubber tree seedling breeding base of Yunnan Institute of Tropical Crop Science had exceeded 1.2 million, covering an area of over 2666.67 hm2. In 2005, Jinghong Farm of Yunnan Agricultural Reclamation introduced mini-seedling budding and conducted three training sessions on miniseedling budding training, with a cumulative total of 310 training persons. From 2005 to $2011,304,848$ plants were transferred out of the nursery, with a survival rate of $46 \%$ and a nursery rate of $95.8 \%$ [36]. Jinghong branch of Yunnan Natural Rubber Industry Co., Ltd. could produce 50,000 mini-seedling buddings in 2007. In 2008, Xishuangbanna successfully introduced mini-seedling budding, and extended to production, and 22,200 miniseedling buddings were raised in private breeding farms and planted in $50 \mathrm{hm} 2$ to rubber farmers [34]. The industrialization and large-scale production of miniseedling budding has been realized in state farms of Guangdong Agricultural Reclamation Tropical Crop Research Institute. The annual production capacity of rubber mini-seedling budding has exceeded 1 million plants [37]. The problem is that the technical team of miniseedling budding is unstable, which affects the industrialization and large-scale production of miniseedling budding. Therefore, it is necessary to train a group of skilled mini-seedling budding workers before the beginning of budding production every year, the new and old mini-seedling budding workers should be trained to be as skilled workers as possible before taking up the job[37]. Furthermore, there are 4 standards related to the study of seedling bud grafting, including one national industry standard [43], one national standard [44], and two local standards [45-46].

According to the above-mentioned production and promotion of mini-seedling budding, the survival rate of bud grafting needs to be further improved, and the increased demand for skilled workers for bud grafting during the season of bud grafting needs to be solved.

\section{THE OUTLOOK FOR ONGOING RESEARCH AND DEVELOPMENT}

Breakthrough on technology and mechanism of rubber seed storage Rubber seeds are moderately recalcitrant seeds that can tolerate moderate dehydration and slightly higher temperatures[47], with a critical moisture content of $13 \%$ [48], and germination decreased by about $40 \%$ when seeds are stored indoors for half a month after falling from the tree. However, rubber seed has a short viability period when exposed to direct light (Table 2).

Table.2: Germination percentage of rubber seed exposed to sunlight

\begin{tabular}{cc}
\hline $\begin{array}{c}\text { Time of exposure to } \\
\text { sunlight(day) }\end{array}$ & $\begin{array}{c}\text { Germination } \\
\text { percentage(\%) }\end{array}$ \\
\hline 1 & 95 \\
2 & 68 \\
3 & 9 \\
4 & 1 \\
5 & 0 \\
\hline
\end{tabular}

Source: Prang Besar Research Station (PBRS)

Therefore, seeds must be collected daily or alternate daily and set for germination immediately. If rubber seeds are not sown in 10-15 days, they lose viability on storage as a result of the production of hydrocyanic acid ( $\mathrm{HCN})$, but over $90 \%$ of the cyanogenic material is consumed to form non-cyanogenic compounds during seedling development, and the cyanogenic glucosides are believed to be transported and metabolized in the young growing tissues[49]. 
Taken together, the initial seed quality, seed moisture content and preservation environment are the three major factors affecting the longevity of seeds. Due to the wide variation in maturity and development stages of rubber seeds, the initial quality of the seeds during storage is not consistent, which affects the stability and repeatability of different storage methods (Table 3 ). The seed storage technology of Hevea brasiliensis can not only be used in seedling raising, but also can be used for rootstock screening. The breakthrough of this technology and mechanism will greatly improve the technical level of rubber tree seedling nursery.

Table.3: Different storage methods of rubber seeds

\begin{tabular}{|c|c|}
\hline Core of storage & Storage time \\
\hline$-7-7^{\circ} \mathrm{C}[50]$ & About a year \\
\hline $\begin{array}{l}\text { Germination and storage in cold storage } \\
\text { at } 12-13{ }^{\circ} \mathrm{C}[51]\end{array}$ & $\begin{array}{l}\text { more than three } \\
\text { months }\end{array}$ \\
\hline River sand and compound for seed [52] & $\begin{array}{c}\text { short and } \\
\text { medium term }\end{array}$ \\
\hline Paraffin embedding [53] & About a year \\
\hline polyethylene glycol 1500[49] & Six months \\
\hline $7^{\circ} \mathrm{C}-10^{\circ} \mathrm{C}[54]$ & three months \\
\hline Sawdust and $10^{\circ} \mathrm{C} / 22^{\circ} \mathrm{C} / 27^{\circ} \mathrm{C}[55]$ & three months \\
\hline Pick seeds from the rubber tree [55] & 92-100 days \\
\hline Water storage [56] & one month \\
\hline
\end{tabular}

Mechanism on budwood quality control of miniseedling budding Budwood quality mainly include diameter and rejuvenation of bud patches. The older the bud stick, the lower budding survival rate and bud breakout rate, the more sensitive to disease of leaf and root, resulting in rubber clone degradation and the decline of growth and yield. The increase rate of rejuvenated rubber buddings in yield was more than that in stem growth [57]. Therefore, rejuvenation of bud stick plays a very important role in improving quality of rubber buddings. Bud sticks rejuvenation is required in rubber tree seedlings (NY_1686-2009), which is regenerated by the method of repeated budding with healthy and strong rootstock and renewed every 5 years. In the technical regulation of rubber tree seedling propagation (NY_16862018), rejuvenation of bud stick is required once every 4-5 years by cutting stock and re-budding or re-planting and bud stick is from bud wood resource nursery. The diameter of rootstock used for seed seedling bud grafting is small (about $0.4 \mathrm{~cm}$ ). The survival rate of $\mathrm{s}$ mini-seedling budding can be improved by selecting the bud strips with the same diameter as the rootstock. At present, the methods of bud proliferation used in mini-seedling budding are as follows: the green cluster buds in the outdoor by repeatedly cutting off and re-sprouting [44], and the young bud stick in the outdoor bud wood nursery (not lignified, $5-8 \mathrm{~cm}$ in the length and $0.3-0.5 \mathrm{~cm}$ in diameter) [58], the proliferation buddings with more than 3 whorls in green house[53], and the micropropagation of anther tissue culture [51]. As mentioned above, bud stick propagation mainly focused on the diameter, but there is little systematic study on the effect and mechanism of bud stick rejuvenation (such as rejuvenation times), on the quality of bud stick and budding. The juvenility characteristics of bud stick can be recovered by rejuvenation (repeated budding of the old bud stick on the new seedling stock or by tissue culture), and the survival rate of mini-seedling budding can be significantly increased by juvenile bud stick, and the budding trees from juvenile buds showed fast growth and high yield in the field. The higher yield of juvenile clones of Hevea brasiliensis was demonstrated by the differential expression of some genes [58-63], transcriptome level [64], proteome level [65] and epigenetic level [66](Table 4), and these results can provide inspirations for the quality control of min-seedling budding propagation, and further more consistent material for early yield screening [67].

\section{Improvement of sprouting uniformity of mini-seedling} budding After cutting back, mini-seedling buddings take different days to sprout, and lead to unsynchronized growth of leaf phenology, which increased intensity of grading buddings before taking out of nursery and production cost. Therefore, to reduce nursery intensity, sound preparation for budding like rejuvenation of bud patches, enough and strong bud patches, vigorous rootstock with strong stem and healthy taproot, preplanting in trays after budding (Table 5) and cutting back at the same time [68] to sprout and grow evenly.

Table.5: Effect of pre-planting on dieback rate of miniseedling budding after transplanting in 6 months

\begin{tabular}{cc}
\hline Pre-planting & dieback rate $(\%)$ \\
\hline Trays with coir & $9.31 \pm 4.79 \mathrm{bB}$ \\
Sand bed & $13.95 \pm 4.01 \mathrm{aA}$
\end{tabular}

Note: For trays, 63 repeats, each repeat contains 240 plants. For sand bed, 36 repeats, each repeat contains 231 plants. 
Table. 4: Genetic, transcriptomic, proteomic, and epigenetic differences between juvenile and mature clones of rubber trees.

\begin{tabular}{|c|c|c|}
\hline Clones & Tissue & Differential expression \\
\hline Unknown & $\begin{array}{l}\text { Leaf, flower, } \\
\text { bud, latex, } \\
\text { bark }\end{array}$ & $\begin{array}{l}H b C M T 1 \text { transcripts accumulated in various examined tissues, with high expression } \\
\text { levels in the leaf and low levels in the latex. } H b C M T 1 \text { transcript expressed at different } \\
\text { levels with the lower in self-rooting juvenile clones than in their donor clones [58]. } \\
H b 14-3-3 a \text { and Hb14-3-3b were differentially expressed in flower, leaves, barks and } \\
\text { latex of Hevea brasiliensis. Hbl4-3-3a transcripts accumulated at relatively high levels } \\
\text { in the barks, while Hb14-3-3b transcripts accumulated at relatively high levels in the } \\
\text { leaves [59]. HbHDTl was differentially expressed in the flower, callus, embryos, leaf, } \\
\text { bud and latex, and was not induced in the latex by jasmone acid and ethylene [60]. A } \\
\text { translationally controlled tumor protein (TCTP) was constitutively expressed in the } \\
\text { latex, leaves and barks, and induced by ethylene [61]. }\end{array}$ \\
\hline Haiken 2[62] & latex & $\begin{array}{l}\text { Suppression subtractive hybridization method showed that comparison with DCs, } 95 \\
\text { genes were upregulated and } 81 \text { downregulated in self-rooting JCs, respectively. } \\
\text { Systematic analyses of the differentially expressed genes between self-rooting JCs and } \\
\text { DCs suggest that rubber biosynthesis, production, and scavenging of reactive oxygen } \\
\text { species may have significant functions in high-yielding self-rooting JCs. }\end{array}$ \\
\hline $\begin{array}{l}\text { CATAS7-33- } \\
97 \\
\text { Haiken2[63] }\end{array}$ & $\begin{array}{l}\text { Flower, } \\
\text { somatic } \\
\text { embryo, leaf, } \\
\text { callus, latex }\end{array}$ & $\begin{array}{l}\text { HbTRX1 was constitutively expressed in all tested tissues. HbTRX1 transcripts } \\
\text { accumulated at relatively low levels in the flower, somatic embryo, and leaves, while } \\
\text { HbTRX1 transcripts accumulated at relatively high levels in the callus and latex. The } \\
\text { HbTRX1 transcript was expressed at different levels, with higher levels in self-rooting } \\
\text { juvenile clones than in their donor clones. }\end{array}$ \\
\hline $\begin{array}{l}\text { CATAS 7-33- } \\
\text { 97, Haiken } \\
\text { 2[64] }\end{array}$ & latex & $\begin{array}{l}\text { Comparative transcript profiling indicated that } 1716 \text { genes were identified as } \\
\text { differentially expressed between self-rooting JCs and DCs. Functional analysis showed } \\
\text { that the genes related to the mass of categories were differentially enriched between the } \\
\text { two clones. Several genes involved in carbohydrate metabolism, hormone metabolism } \\
\text { and reactive oxygen species scavenging were up regulated in self-rooting JCs. }\end{array}$ \\
\hline Haiken 2[65] & latex & $\begin{array}{l}\text { The proteomic approach showed that comparison with donor clones, } 13 \text { proteins were } \\
\text { upregulated, } 11 \text { proteins were downregulated in self-rooting juvenile clones. These } \\
\text { proteins were classified as carbohydrate and energy metabolism, secondary metabolism, } \\
\text { signal translocation, transcriptional regulation-related, protein synthesis and } \\
\text { degradation, transport, nucleoside acid process, lipid metabolism. }\end{array}$ \\
\hline $\begin{array}{l}\text { CATAS 8- } \\
79[66]\end{array}$ & $\begin{array}{l}\text { leaf at bronze } \\
\text { stage }\end{array}$ & $\begin{array}{l}\text { The genomic DNA methylation showed that the juvenile clones was } 33.2 \% \text { and the } \\
\text { mature clones was } 22.9 \% \text {, and different expressed fragments were related with } \\
\text { metabolism and cell growth. }\end{array}$ \\
\hline
\end{tabular}

Container of mini-seedling budding and mechanized seedling nursing Different container mini-seedling buddings can be grown depending on the environment in which they are planted, e.g., mini-seedling buddings raised in small root-tubes with 2-3 leaf whorls are suitable for remote mountainous areas, mini-seedling buddings raised in large container with 4-6 leaf whorls are suitable for flat and of high value for intercropping. Currently, sales of rubber buddings are also severely affected due to the ongoing downturn in rubber prices, and the exploration of mechanized seedling nursery in container of mini-seedling budding seedling is still lagging.

\section{CONCLUSION}

Mini-seedling buddings are widely raised in China rubber plantation for the characteristics of short nursery period, low labor intensity, large number of seedlings per unit area, easy transportation and planting, well-developed taproot and intact root system, high survival rate after planting, fast growth, strong tolerance to drought, wind and cold, and early tapping. However, there are several scientific problems such as seed storage, budwood quality, sprouting uniformity and mechanized container nursing to be solved in the future. 


\section{ACKNOWLEDGEMENTS}

This work was supported by the earmarked fund for China Agriculture Research System (CARS-34-YZ4).

\section{REFERENCES}

[1] Huang S (1988) Mini-seedling rootstock budding technology research bulletin. Tropical Crops Research, (2):60.

[2] Huang SF (1989) A new method of rubber asexual propagation Mini-seedling budding of Hevea brasiliensis. Chinese Journal of Tropical crops (01):2531.Puangbut, D., S. Jogloy, and N. Vorasoot, 2017: Association of photosynthetic traits with water use efficiency and SPAD chlorophyll meter reading of Jerusalem artichoke under drought conditions. Agricultural Water Manage 188, 29-35.

[3] Lin WF, Huang SF, Xie GS, Cai MD, Chen JM (1998) Mini-seedling budding of Hevea brasiliensis. Chinese Journal of Tropical crops (03):8-15.

[4] Wang BZ, Dong JH, Sun MZ (1992) Fundamental physiology of budding success of mini-seedling budding of Hevea brasiliensis. Chinese Journal of Tropical Crops (02):9-14.

[5] Wang BZ, Dong JH, Pan XX, Huang JW, Pan HY, Hu MY (1993) Physiological parameters of roots in relation to budding success of mini-seedling budding. Chinese Journal of Tropical Crops (01):9-14.

[6] Chen XT (2008) In vitro Rapid Propagation on min-type bud patches and its application in mini-seedling budding of Hevea brasiliensis. World Tropical Agriculture Information (11):28.

[7] Chen XT, Zhang XJ, Wang Y, Wu KX (2008) A method of mini-seedling budding of Hevea brasiliensis by raising micro-type budwood., $\mathrm{p} 7$.

[8] Gui MC, Liang GP, Duan AA, Xiao SY (2011) The effect of temperature on in vitro mini-type budding stick of Hevea brasiliensis. Tropical Agricultural Science and Technology 34 (03):5-7.

[9] Huang Z, Wang LQ, Liang FY, Chen HJ, Zhou GM, Zhou JZ, Zhang N, Ni YM, Zhang QQ (2012) A method of multiplying green and small budwood in mass production., $\mathrm{p}$ 5.

[10] Zhang N, Huang Z, Liang QL, Liang FY (2012) Research on multiplication technology of green and small budsticks of Hevea brasiliensis. Chinese Journal of Tropical Crops 33 (05):881-885.

[11] Liang GP, Sun XL, Ning LY, Gui MC, Tian H, Huang FX, Guan Y, Li L (2014) A method of mini-seedling budding of Hevea brasiliensis by raising young budwood and budding., p 5.

[12] Yu JJ, Tang M, Tian H, Li L, Guan Y, Liang GP, Li XQ, Gui MC (2018) The effect of different lignified scions on the growth of grafted mini-seedling of Hevea brasiliensis. Tropical Agricultural Science \& Technology 41 (02):5-8.
[13] Sun XL, Tian H, GUI MC, Tang M, Liang GP (2019) Experiment of mini-seedling grafting with different buds from different budwoods of rubber trees. Tropical Agricultural Science and Technology 42 (4):1-3, 8.

[14] Tang M, Tian H, Liang GP, Li XQ, Gui MC (2019) The differences of leaf morphology of grafted mini--seedling from mature and juvenile types of Hevea brasiliensis clones. Tropical Agricultural Science and Technology 42 (01):2124.

[15] Zhou J, Wang J, Lin WF, Cai MD, Zhang RQ (2013) Rootstock Treatments on the Growth of Three Kinds of Budding of Rubber Tree. Chinese Agricultural Science Bulletin 29 (16):29-31.

[16] Zhou J, Lin WF, Wang J, Cai MD, Zhou LJ (2014) Effect of Different Truncated Rootstock Treatments on Growth. Guizhou Agricultural Sciences 42 (11):119-122.

[17] Chen JM, Cao JH, An F, Cai XQ, Zou JX, Wang J (2009) A needling method to pick bud for mini-seedling budding of Hevea brasiliensis., p 5 .

[18] Zhou J, Lin WF, Cai MD, Wang J, Zhou LJ, Chen XH, Zhang XC, Zeng XH (2014) A method of bud-picking of mini-seedling budding of Hevea brasiliensis., $\mathrm{p} 6$.

[19] Huang SF, Lin WF, Wang BZ (1994) Continuation research on mini-seedling rootstock budding of Hevea brasiliensis techniques for promoting the sprouting. Tropical crops research (02):8-14.

[20] Chen HJ, Xie GS, Cai MD (2006) Promotion of scion bud in mini-seedling rootstock budding of Hevea brasiliensis using different combinations of phytohormones. Chinese Journal of Tropical Crops (02):1-5.

[21] Zhang N, Liang QL, Huang CH, Huang Z, Liang FY, Zhou SX, Huang MC (2012) A method of promoting sprout of mini-seedling budding of Hevea brasiliensis., p 5.

[22] Chen XH, Lin WF, Zhou J, Wang J, Cai MD, Yao XC (2014) A method of improving consistency on sprout and growth of mini-seedling budding of Hevea brasiliensis., $\mathrm{p} 7$.

[23] Wang JK, Wang LF, An F, Xie GS (2015) Plant growth regulator stimulation on sprout and growth of mini-seedling rootstock budding of Hevea brasiliensis. Chinese Journal of Tropical Agriculture 35 (04):4-10.

[24] Zhang N, Huang Z, Pan Y, Li PY (2011) Factors Influencing Iron Deficiency Chlorosis of Container Rubber Seedlings and Correction Technique. Chinese Journal of Tropical Agriculture 31 (05):4-8.

[25] Chen Q, Zhou J, Wang J, Lin WF, Li LP (2018) Effects of different water and fertilizer drip irrigation treatments on growth of rubber mini-seedling polybag-raised buddings. Journal of Southern Agriculture 49 (03):525-529.

[26] Zhou J, Chen Q, Wang J, Lin WF (2018) Effect of different mediums on the growth of rubber small polytube-raised buddings. Journal of Agricultural Science and Technology 20 (02):33-38.

[27] Zhou J, Wang J, Lin WF, Cai MD (2013) Effect of different mediums on the growth of rubber container buddings. China Tropical Agriculture (05):57-59.

[28] Lin WF, Xie GS, Huang SF, Cai MD, Chen JM (1999) Multi-spot experiment and primary demonstration of mini- 
seedling budding of Hevea brasiliensis. Chinese Journal of Tropical Agriculture (03):39-43.

[29] Zhang YY, Wang JK, Yang C, Xie GS (2013) Effect of chilling stress on physiological characteristics of two kinds of rubber seedlings. Southwest China Journal of Agricultural Sciences 26 (02):559-564.

[30] Hu JL, He XY, Chen K, Zhang YN (2015) Comparison on drought-tolerance of three planting materials of Hevea brasiliensis. Modern Agriculture Technology (21):157-158.

[31] Liu ZL, Lin BJ (2011) Introduction and extension of miniseedling rootstock budding of Hevea brasiliensis in Yunnan Province. Tropical Agricultural Science and Technology 34 (01):7-9.

[32] Mini-seedling budding of Hevea brasiliensis (2018). http://www.catas.cn/xjs/contents/572/126277.html.

[33] Lin WF, Xie GS, Huang SF, Cai MD, Chen JM (1999) Multi-spot experiment and primary demonstration of miniseedling budding of Hevea brasiliensis. Chinese Journal of Tropical Agriculture (03):39-43.

[34] Liu ZL, Lin BJ (2011) Introduction and extension of miniseedling rootstock budding of Hevea brasiliensis in Yunnan Province. Tropical Agricultural Science and Technology 34 (01):7-9.

[35] Sun XL, Liang GP, Gui MC, Ning LY, Tian H, Huang Q (2017) A method of rapid nursery for mini-seedling budding of Hevea brasiliensis., p 6.

[36] Ding C, Li B, Wang QB, Guo FX (2012) The introduction and application of mini-seedling rootstock budding of Hevea brasiliensis. Bulletin of agricultural science and technology (05):223-225

[37] Chen HJ, Huang Z, Wang LQ, Liang FY (2011) Familiarization and application promotion of mini-seedling rootstock budding of Hevea brasiliensis. China Tropical Agriculture (04):50-51.

[38] Liao JX, Chen DJ, Yao LY, Zheng QK (2018) Analysis of familiarization and application promotion of mini-seedling rootstock budding of Hevea brasiliensis. Peasant Family Technology (11):13.

[39] Ni YM, Huang Z, Wang LQ, Liang FY, Zhou JZ, Zhang QQ, Jiang ZH (2012) Factory propagation of rubber seedling budding technology. Tropical Agricultural Engineering 36 (06):18-21.

[40] Wang SS, Hu NS, LI QY, Chen W (2012) Exploration and practice of mini-seedling rootstock budding of Hevea brasiliensis. Modern Horticulture (14):6.

[41] Chen W, Li QY, Liu JR, Wang SS, Hu NS (2010) Production trials of mini-seedling rootstock budding of Hevea brasiliensis. Tropical Agricultural Engineering 34 (01):45-48.

[42] Huang Z (2011) Optimization and improvement of miniseedling rootstock budding of Hevea brasiliensis. Tropical Agricultural Engineering 35 (04):28-32.

[43] Technical Committee for Standardization of Tropical Crops and Products of Ministry of Agriculture and Rural Development (2009) rubber tree seedlings. GBT17822.22009.
[44] Technical Committee for Standardization of Tropical Crops and Products of Ministry of Agriculture and Rural Development (2018) The technical regulation of rubber tree seedling propagation. NYT 1686-2018.

[45] General Bureau of Agricultural Reclamation of Yunnan Province (2019) The technical regulation of mini-seedling budding production of Hevea brasiliensis. DB5328/T 102019.

[46] Market supervision and Administration Bureau of Xishuangbanna Dai Autonomous Prefecture (2016) The technical regulation of mini-seedling budding production of Hevea brasiliensis. DB5328T10-2016.

[47] Tian XM, Li HL, He Y, Hong QM, Hu WB, Li Q (2014) Research progress on recalcitrant seeds storage of tropical crops. Chinese Journal of Tropical Agriculture (8):52-58.

[48] Zhou LJ, Lin WF, An F, Zhou J, Wang J. Chen XH, Zhang XC, Zeng XH, Zou JX (2013) A storage method of rubber seeds., p 6.

[49] Priyadarshan, P.M. (2011) Biology of Hevea Rubber. Wallingford, UK: CABI, 24.

[50] Xie GS, Huang YF, Lin WF, Chen JM, An F, Tao ZL, Wu ZX, Cao JH, Wang J, Zou JX, Cai MD, Zeng XH, Zhang XC (2008) Low temperature storage of rubber seeds., $\mathrm{p} 6$.

[51] Chen XT (2008) Storage technology of rubber seeds., p 4.

[52] Zhou LJ, Lin WF, An F, Zhou J, Wang J. Chen XH, Zhang XC, Zeng XH, Zou JX (2013) A storage method of rubber seeds., p 6.

[53] Lin WF, Wang J, Wei HQ, Cao JH, An F, Xie GS (2008) A storage method of rubber seeds., $\mathrm{p} 6$.

[54] Rubber plantation and processing technologies (2009). Kuala Lumpur, Malaysia: Malaysian Rubber Board, 49.

[55] Feng GS (1996) Experiment on rubber seeds sown in spring and stored in winter. Journal of Yunnan Tropical Crops Science \& Technology 19 (4):33-34.

[56] Fu JR (1991) Recalcitrant seed. Plant Physiology Communications 27 (6):402-406.

[57] Carron MP, Tian L (2010) Field trials network emphasizes the improvement of growth and yield through micropropagation in rubber tree (Hevea brasiliensis, Muëll. Arg.). World Tropical Agriculture Information (6):1-6.

[58] Li HL, Wang H, Yang ZP, Guo D, Peng SQ (2015) Cloning and Expression Analysis of HbCMT1 in Hevea brasiliensis. Journal of Plant Genetic Resources 16 (4):842-847.

[59] Li HL, Guo D, Peng SQ (2010) Cloning and expression of 14-3-3 protein genes from Hevea brasiliensis. Chinese Journal of Tropical Crops 31 (09):1452-1457.

[60] Lu HZ, Li HL, Guo D, Peng SQ (2010) Cloning and Expression Analysis of HbHDT1 in Hevea brasiliensis. Chinese Journal of Tropical Crops 31 (1):59-64.

[61] Liang XL, Li HL, Peng SQ (2009) Cloning and Expression of HbTCTP in Hevea brasiliensis. Molecular Plant Breeding 7 (1):188-193.

[62] Li H, Guo D, Peng S (2014) Differential gene expression profiles in latex from Hevea brasiliensis between selfrooting juvenile and donor clones. Plant Growth Regulation:65-71. 
[63] Li H, Lu H, Guo D, Tian W, Peng S (2011) Molecular characterization of a thioredoxin $\mathrm{h}$ gene (HbTRXl) from Hevea brasiliensis showing differential expression in latex between self-rooting juvenile clones and donor clones. Mol Biol Rep 38 (3):1989-1994.

[64] Li H, Guo D, Zhu J, Wang Y, Chen X, Peng S (2016) Comparative Transcriptome analysis of latex reveals molecular mechanisms underlying increased rubber yield in Hevea brasiliensis self-rooting juvenile clones. Front Plant Sci 7.

[65] Li H, Guo D, Lan F, Tian W, Peng S (2011) Protein differential expression in the latex from Hevea brasiliensis between self-rooting juvenile clones and donor clones. Acta Physiol Plant 33 (5):1853-1859.

[66] LI HL, Li WG, Yang ZQ (2014) MSAP Analysis of Juvenile Clones and Mature Clones of Hevea brasiliensis. Chinese Journal of Tropical Crops 35 (4):617-621.

[67] Bao J, Zhang SX, Shi MJ, Tian WM (2014) Consistency analysis of latex production capacity in rubber tree clones. Chinese Journal of Tropical Crops 35 (11):2173-2178.

[68] Chen XH, Lin WF, Zhou J, Wang J, Cai MD, Yao XC (2014) A method of improving consistency on sprout and growth of mini-seedling budding of Hevea brasiliensis., $\mathrm{p} 7$. 